\title{
Non-standard working time: an international and comparative analysis
}

Article

Accepted Version

Richbell, S., Brookes, M., Brewster, C. and Wood, G. (2011) Non-standard working time: an international and comparative analysis. The International Journal of Human Resource Management, 22 (4). pp. 945-962. ISSN 1466-4399 doi: https://doi.org/10.1080/09585192.2011.555135 Available at https://centaur.reading.ac.uk/25611/

It is advisable to refer to the publisher's version if you intend to cite from the work. See Guidance on citing.

To link to this article DOI: http://dx.doi.org/10.1080/09585192.2011.555135

Publisher: Taylor \& Francis

All outputs in CentAUR are protected by Intellectual Property Rights law, including copyright law. Copyright and IPR is retained by the creators or other copyright holders. Terms and conditions for use of this material are defined in the End User Agreement.

\section{www.reading.ac.uk/centaur}

\section{CentAUR}

Central Archive at the University of Reading 
Reading's research outputs online 


\title{
Non-standard working time: an international and comparative analysis
}

\author{
Suzanne Richbell* Sheffield University Management School, Sheffield, UK \\ Michael Brookes, Middlesex University, Hendon, UK \\ Chris Brewster, University of Reading, Reading, UK \\ Geoffrey Wood, Sheffield University Management School, Sheffield, UK
}

Words (excluding abstract, tables and references): 6837

Words (including abstract, tables and references): 9089

*Corresponding author: $\underline{\text { s.m.richbell@ } \text { sheffield.ac.uk }}$ 


\section{Non-standard working time: an international and comparative analysis}

This paper uses the large-scale Cranet data to explore the extent of non-standard working time across Europe and to highlight the contrasts and similarities between two different varieties of capitalism (coordinated market economies and liberal market economies). We

explore variations in the extent of different forms of non-standard working time (overtime, shift working and weekend working) within these two different forms of capitalism, controlling for firm size, sector and the extent of employee voice. Overall, there was no strong link between the variety of capitalism and the use of overtime and weekend working though shift working showed a clear distinction between the two varieties of capitalism. Usage of non-standard working time in some service sectors was particularly high under both forms of capitalism and service sector activities had a particularly marked influence on the use of overtime in liberal market economies. Surprisingly, strong employee voice was associated with greater use of non-standard working time

Keywords: non-standard working time; overtime; shift working; weekend working. 


\section{Non-standard working time: an international and comparative analysis}

\section{Introduction}

Working time is a key issue in modern work and employment relations. For many people, the time at which work takes place is irrelevant - for accountants, designers and computer programmers only the final deadline for the delivery of the services they provide matters. For others, particularly those engaged with the public, where their services are dependent on their availability or their production depends on access to goods or equipment, availability and working time are crucial. For yet a third group, flexibility is what matters: academics fit in the work to prepare papers around their teaching and administrative tasks. In all cases, work outside the normal working day is of increasing importance. However, this is unlikely to be the same in all economies and the extent of such work may vary between different forms of capitalism.

It could be argued that firms operating in lightly regulated contexts are freer to redeploy people as and when managers choose, even if this is not in accordance with employee preferences. Conversely, the use of non-standard working time may be more attractive in more regulated contexts where flexible working hours may give firms more scope to 
adjust relative workforce sizes without having to make premature hirings or redundancies. In contrast to these arguments for differences between different forms of capitalism, it may be that specific technology or customer needs may make non-standard working the norm in particular industries regardless of context. In short, a comparative study of the relative incidence and nature of non-standard working time may tell us a lot about the distinguishing features of specific varieties of capitalism, and the strategic choices regarding HRM practices that are likely to be made by firms in different contexts. Given the evidence of distinctiveness of business systems found in the Cranet dataset when looking at other areas of HRM (Brewster et al. 2007; Brewster et al. 2004), it is important to explore whether differences between varieties of capitalism also exist in the area of non-standard working time.

The paper explores these issues as follows. Firstly, it outlines the nature of non-standard working time and the ways in which non-standard working time might vary within the two different types of capitalism identified by Hall and Soskice (2001). The influence of differences in firm sizes, sectoral mix and the degree of employee voice within the different forms of capitalism is noted. Then we outline our methodology and measures. The results and a discussion of the results precede a conclusion outlining some of the implications of our findings.

\section{Flexibility and non-standard working time}




\section{Forms of Flexibility}

There are many different forms of workplace flexibility or, to use the terminology current in the US literature, contingent employment. Polivk and Nardone (1989:10) define 'contingent' employment in broad terms as "any arrangement that differs from full-time, permanent, wage and salary employment". These have generally been grouped under three headings: numerical (including contractual) flexibility, functional flexibility and temporal flexibility (Brewster 1998) and it is clear that the use of these forms varies between countries (Brewster, Mayne and Tregaskis, 1997; Raguram, London and Larsen, 2001; Tregaskis and Brewster 2006).

Numerical flexibility is the ability of organisations to adjust the size of the workforce through hiring, lay-offs and dismissals whilst the sub-category contractual flexibility concerns the nature of the employment relationship: whether indeed it is an employment relationship or maybe an individual contract for services, and whether it is permanent or short-term. Functional flexibility represents the ability of workers to do different tasks within the same organisation (Almond and Gonzalez, 2006; Wood et al. 2006). This may involve greater variety both in tasks and in decision making powers (Marsden 1999: 132). Temporal flexibility is used either to cover the employer's ability to alter total number of hours worked or to refer to working time which occurs outside the standard working day, week, month or year. It is temporal flexibility and, in particular, the second of these definitions of temporal flexibility that is our focus here. Admittedly, the most common 
form of flexible working time is part-time work, but as this may or may not be worked outside "normal" working hours, it is not considered separately here ${ }^{1}$.

Standardised working arrangements were introduced with the industrial revolution and have applied in developed economies, for most of the time since then, to a majority of production and service workers, though not to many workers in such areas as agriculture, emergency services and parts of the service sector such as hotels. Standard working patterns are part of a broader social consensus involving synchronisation with leisure and educational time. Recently, however, driven by the increasing demands for competitiveness, firms have had to respond to changes in demand through the remaking of production and by altering the way working time is used (e.g. moving from fixed to more flexible schedules). In the service sector, there are growing demands for services such as retailing (Richbell and Kite, 2007) to be available to the public for much longer time periods and, in some cases, on a "twenty-four/ seven" basis (Kreitzman, 1997; Wilson et al 2005).

The literature on working time concentrates on two main issues: the overall duration of work (Lee, McCann and Messenger, 2007) and the times of the day or night during which it takes place (Berg et al. 2004). Non-standard working time (hereafter NSWT) is work outside of the "normal" working day. Of course, the normal working day varies with country and context, but standard hours are defined normally in terms of the Western office based 8 hours per day, Monday-Friday, during daylight (McOrmond, 2004).

\footnotetext{
${ }^{1}$ For more on the specific issues pertaining to part time work see, for example, Ackers and Al-Sawad (2006) and Harris (2002).
} 
NSWT falls outside this standard day/week. The move to NSWT was emphasised by Boisard et al (2002) who, drawing on a survey of the European Union's then 15 member countries, revealed that standard day work is now undertaken by only a minority of the workforce. Typical elements of NSWT are overtime, shift working and weekend working.

Overtime: Supiot (2001) argues that, historically-speaking, the primary form of temporal flexibility has been in the form of overtime. Overtime can be defined as hours worked in addition to the normal working day/week, sometimes paid at a multiple of the standard rate, though much work in NSWT is unpaid (particularly among professionals and managers, where non-standard working is driven by company norms and/or individual ambition). This means that whilst employers may have to spend more on pay, they do not have to renegotiate wage rates (Marsden 1999), nor face an increase in indirect wage related costs (e.g. pensions, other benefits). Overtime is commonly regulated through restricting the total number of hours that may be worked within a week and through the requirement for some degree of prior authorisation.

Shift working: Survey evidence from Boisard et al (2002) showed nearly $20 \%$ of European Union workers involved in shift work, or systems in which work is carried out at set times of the day or night outside the normal working day and where individuals may rotate between different work time patterns. Shift work was established either to make greater use of expensive plant or property or to provide services on a continuous basis. Originally shift working tended to follow simple patterns but the advent of 
computerisation meant that managers could institute quite complicated arrangements with varying and more flexible patterns of work (Brewster 1998). Competitive pressures have forced firms to find ways of enhancing output without increasing overall staff numbers or when cutting them (Williams and Adam-Smith 2006: 229).

Weekend working: A specific form of NSWT is weekend working. The rationale is the same as for other forms of NSWT (Hollinshead et al. 1999; Gall 2003). Although weekend working may be negotiated by individual employees in response to personal circumstances, it is most likely to be driven by "business needs" (Hollinshead 1999: 483).

\section{Flexibility, NSWT and Work/non-work Integration}

Moves away from standard day work impact on work/non-work integration. Changes to working time may be either beneficial or disadvantageous for the individuals concerned. On the one hand, adjustment in working time may allow for better work/non-work balance, and for a more effective response to the personal needs of individual employees (Martin 2006). On the other hand, evidence from Europe suggests that moves to nonstandard working in the form of shifts or irregular hours lead to higher levels of stress and general fatigue (Boisard 2003). Working time adjustments may weaken the individual positions of employees, and make it harder for them to resist further redefinitions (Marsden 1999). Berg et al (2005) argue for a greater focus on the issue of control over working time and for employees to have some control of the working relationship. Evidence from Cousins and Tang (2004) shows such control is possible but is spread 
unevenly throughout Europe, with 'negotiated flexibility' in the Netherlands giving workers greater control over working time. Wilson et al. (2005), aware of the impact on work/non-work balance, focus on family involvement in the training of shift workers and the exploration of social coping strategies.

Working time is central to many employment relationships. The nature of NSWT in particular is linked to the degree of general flexibility in working arrangements, and relations within and beyond the firm. The relative ability of firms to expand the extent of NSWT is bound up with the prevailing labour market traditions, the law and custom. Yet, in the growing body of comparative literature on capitalism, work and employment relations (for example Whitley 1999; Hall and Soskice 2001; Lane and Wood, 2009), the issue of NSWT is a relatively neglected one.

\section{Varieties of capitalism and working time}

Over the past two decades, there has been a proliferation in the literature on comparative capitalisms; seeking to link dominant inter- and intra- firm practices with particular national institutional configurations and the nature of relationships between key actors and stakeholders and searching for clusters of countries in which the same factors

predominate (Lincoln and Kalleberg 1990; Hall and Soskice 2001; Whitley 1999). A common distinction is drawn between, on the one hand, the stakeholder or coordinated varieties of capitalism, such as those encountered in continental North Western Europe and the developed economies of the Far East and, on the other, the liberal market or 
shareholder orientated varieties found in the Anglo-American economies (Hall and Soskice, 2001; Dore, 2000; Almond and Gonzalez 2006). The former, the coordinated market economies (CMEs) are characterised in part by more cooperative forms of work and employment relations, with high levels of delegation to employees and interdependence between managers and employees (Whitley 1999; Hall and Soskice 2001). The latter, the liberal market economies (LMEs), are characterised by lower levels of delegation and interdependence (Hall and Soskice 2001).

There are limitations to such dichotomous approaches to varieties of capitalism, in particularly in relation to the CME category, which encompasses quite a disparate set of countries. Amable (2003) would divide CME countries into two distinct groups (continental European and social democratic) but he acknowledges that they have much in common in key areas particularly pertinent to this analysis. Both groups have common legal systems and centralised bargaining and, hence, a great deal more protection for employees, including issues such as the usage of overtime and other non-standard working practices (Djankov et al. 2003; Amable 2003; La Porta et al. 1998). Hence, we have opted to remain with a dichotomous approach to varieties of capitalism, whilst recognising the relevance of multi-model approaches for understanding differences in firm level practices in a range of other areas (Brewster et al. 2007).

We would also stress two important caveats. First, we recognise that a minority of firms in both varieties of capitalism may opt to stand outside the majority approach for that form of capitalism and behave more like firms from the opposite paradigm. Indeed, 
recent research points to the coexistence of alternative production paradigms within specific national contexts, even if clear differences between nations remain (Brewster et al. 2006). Second, we recognise that the variety of capitalism is not the sole determinant of NSWT and, following Berg et al (2004), note that other key issues affecting the usage of NSWT include government regulations, informal norms, the state of the external labour market, the sector within which a firm is operating (often tied to sector specific technologies), firm size, and the countervailing power of employees via mechanisms for participation.

\section{Coordinated Market Economies (CMEs)}

Within coordinated markets, firms may offset the numerical flexibility problems associated with a high degree of employment protection through attaining numerical flexibility by other means such as adjusting the time worked (Tregaskis et al. 1998; Almond and Gonzalez 2006). Regulations in these economies generally restrict the use of numerical flexibility and focus on functional and temporal flexibility. In the latter case, legislation on alternative working time arrangements (Wood et al. 2006) discourages the use of some practices (such as extensive overtime) and encourages the greater use of others (such as adjustment of the working week, particularly in terms of shortening it in order to preserve jobs in times of reduced demand (Harcourt and Wood 2007). In contexts where employee rights are protected more clearly under the law, workers have an external point of reference which can help protect their rights, make them more aware of what can be expected, and hence, better able to cope with changes in working circumstances (Marsden 1999). Berg et al (2004) found that within CMEs, non-standard 
working arrangements are more likely to be negotiated; hence, the nature and form of non-standard working is likely to be related to union strength and bargaining arrangements. In practice, atypical working hours in these economies may often take the form of an annualised contract specifying total working hours and permitting variable working time; the latter may or may not take place outside of normal working hours.

Why would non-standard working time be less likely to occur in CMEs? Whilst it is not disputed that a degree of flexibility is built into centralised agreements that characterise employment relations across large areas of the economy in CMEs, any major or systematic adjustment in working time away from a commonly considered "norm" would require agreement at some level. Employees and their collectives are in a stronger position vis-à-vis managers in CMEs (Hall and Soskice 2001: 57). Union desires to promote "good" job creation and, hence, enlarge the pool of potential members (Hyman 2006; Gall 2003) are likely to mean that, in contexts where they are relatively strong, they are unlikely to be favourably disposed to agree to the systematic use of overtime or complex shift working, or agree to the imposition of practices that may facilitate redundancies. The systematic usage of overtime in specific sectors associated with poor quality working conditions may also be unattractive to employees and their representatives. Of course, individual workers may, in specific cases, welcome the chance for additional earnings via overtime but, given the above mentioned concerns, it is more likely that they will be hostile or lukewarm to it. Quite simply, to an individual working overtime it may be beneficial to her/him (in terms of extra pay or being seen to be more diligent), but it can have collective consequences (such as leaner staffing and a 
creeping expectation that workers can and should work longer). This would mitigate the use of overtime in contexts where unions are stronger, or indeed, where workers have other effective forms of collective representation at the workplace.

In contrast, employees may well be inclined to agree to shorter working time, if the alternative is large scale redundancies (Harcourt and Wood 2007; Wood et al. 2006). Many firms operating in CMEs base their competitiveness on high quality incrementally innovative production that requires workers actively to invest in developing themselves in organisationally specific ways that benefit their employer whilst restricting their marketability(Hall and Soskice 2001). This is more likely to emerge in contexts where jobs are more secure and a greater degree of meaning is vested in working life (Sayer 2006: 209-212; Harcourt and Wood 2007). Finally, in areas covered by collective bargaining, employers are less able to adjust terms and conditions of work. This means that the ad hoc introduction of overtime or changes in working hours between rounds of annual collective bargaining will be more difficult (Wood et al. 2006: 176-180).

\section{Liberal Market Economies (LMEs)}

Within liberal market economies, firms are rather more likely to make use of redundancies, since restriction on the owners' rights to terminate employment are more limited. Light regulation allows firms to make greater use of overtime and thus save on recruitment and induction costs. Why are LME-based firms more likely to adopt nonstandard working time than their CME-based counterparts? One reason is that the relative weakness of unions and collective bargaining in LMEs allows employers to 
adjust the terms and conditions of employment more easily (Hall and Soskice 2001: 57). Whilst unions may have an interest in allowing some flexibility in working time to avoid redundancies, the widespread usage of overtime would constrain future job creation and may detract from the quality of working life. Conversely, some employees may favour non-standard working time owing to the difficulty of balancing family commitments in contexts where the state provision for childcare is poor or in order to secure more pay. Any additional pay for overtime is likely to promote a more instrumental approach to work and this is more likely to be encountered in lightly regulated environments (Sayer 2006). Furthermore, in the civil law systems associated with LMEs, employee rights generally are weaker, both in formal law and in their enforcement (Djankov et al. 2003; Harcourt and Wood 2004). Inter alia, there are fewer restrictions on employers making use of NSWT.

There is considerable empirical evidence to support this rationale. The average annual hours worked in liberal markets is higher than in coordinated ones (OECD 2003). The hours worked in typical LMEs such as the USA, Canada and the UK are higher than those in typical CMEs such as Austria and Germany. Where temporal flexibility is used in LMEs, work outside of normal working hours will most typically take the form of overtime (Ackers and Al-Sawad 2006), in contrast to the annualised contracts of the CMEs. In the UK, the EU working time regulations, that limit overall hours worked, were adopted with a UK-specific concession that permits workers to opt out of a 48 hour maximum working week, through undertaking overtime or longer shifts (Ewing 2003; Williams and Adams-Smith 2006). This concession would suggest that the UK system is 
more dependent on non-standard working than the CMEs, who generally adopted the ruling. Kenner (2004: 591) notes that the opt-out allows the UK to maintain its 'essentially deregulatory approach to working time' particularly in the private sector where the level of collective bargaining is lower. Indeed, formal working time in Britain is the longest in the EU (Ewing 2003).

\section{Statement of Hypotheses}

Of course, as noted earlier, any differences between the extent of NSWT in CMEs and LMEs will be mediated by a variety of factors. In our analysis, we consider firm size, industrial sector and the strength of employee voice. We use firm size only as a control variable as the truncated nature of the size variable in our data set (discussed below) means that it is inappropriate to undertake a detailed analysis of the effects of size. We identify three hypotheses for examination.

\section{Variations in NSWT}

H1: Overtime and shift working are more common in LMEs than CMEs.

It appears likely that within liberal market economies, the usage of overtime and shift working will be higher than it will be in the CMEs. This reflects the greater ability of employers to adjust the terms and conditions of employment, including fewer legal restrictions on the usage of overtime and weaker unions, that make it easier to deploy 
workers "unfettered by time constraints" (Hyman 2006: 192) as well as the greater likelihood of more instrumental attitudes to work. Employees are more likely to accept working under less favourable conditions if work is primarily seen as a means to material rewards (Sayer 2006).

\section{Sectoral differences in NSWT}

H2a: Sector will partially determine the extent of NSWT.

H2b: The service sector is more likely to be an influence on the extent of NSWT in LMEs than CMEs.

What constitutes "normal" working time varies from sector to sector. Overtime and work at unsocial hours are common within many areas of the service sector (Williams and Adams-Smith 2006). As noted earlier, some sectors (health, emergency services, hotels) are inherently twenty-four hour operations and therefore, in respect of NSWT, are unlikely to be affected by the variety of capitalism in which they operate. In other sectors there is likely to be more variation between different forms of capitalism. Firstly, within the service sector, certain types of personal services (e.g. fast food, call centres) are more likely to operate after hours than others (conventional retailing); often the former tend to be relatively low value added (Hyman 2006). A body of literature suggests that low value added personal services are likely to be a particularly prominent feature of economic life in LMEs (Hyman 2006; Harcourt and Wood 2007; Thelen 2001). Secondly, it is more economic to operate certain types of machinery on a continuous or near continuous basis, reflecting either technology or the nature of demand and delivery 
(e.g. energy provision); there is little in the literature to suggest such sectoral effects will be more pronounced in a specific variety of capitalism. Finally, given that weekend working may represent a product of technology (as noted earlier, some forms of machinery may function best under continuous operation) or industry (for example, entertainment), we would not expect a significant variation in the incidence of weekend working according to variety of capitalism.

\section{Employee Voice and NSWT}

H3: The presence of collective employee voice influences the extent of NSWT: overtime is more likely to be encountered where representative employee voice (collective bargaining and/or works councils) is absent or weak as in LMEs.

We noted that certain forms of NSWT are more likely in contexts where employee voice is relatively weak. In other words, effective employee voice mechanisms (via collective bargaining and/or works councils) are likely to discourage the usage of overtime. If working longer is unattractive then workers are likely to exercise voice to deter it. This does not mean that all workers will necessarily be hostile to overtime in all cases. They may welcome the opportunity for additional earnings, or to contribute to organisational survival - and hence safeguard their jobs in hard times. However, unions are unlikely to

press for overtime working at the collective bargaining table, and may oppose it, either when such working is unpopular per se with their constituents, or where it may facilitate redundancies or generally leaner staffing. This means that it is likely that employee voice 
will mitigate the usage of overtime. Hence, it is worth interrogating the link between NSWT and employee voice.

\section{Data and method}

The data used to test these hypotheses are taken from the Cranet survey. This survey contains evidence on human resource management and industrial relations within private and public sector organisations in 22 European countries as well as others (Brewster et al 2004). For the purpose of this analysis, we use the 2003/4, survey and focus on data relating to the private sector (which includes a number of 'public sector' activities which have been outsourced to private sector providers). Five European countries fitting easily into the liberal market and co-ordinated market economy categories are selected as being the most appropriate, with the UK being used as the liberal market economy and Germany, Austria, Sweden and Denmark used as appropriate examples of co-ordinated market economies. These four countries, which we take as representative of CMEs, all fall into Whitley’s (1999: 43-44) “collaborative” category.

The survey targets the most senior HRM professional within the establishment and covers a wide range of matters relating to company policies and practices in the HRM area. The data for each country is broadly representative with respect to proportion of industrial sectors and numbers employed (full technical details are provided by Brewster et al., 2004). In the five countries used, the companies surveyed were those recorded as having more than 200 employees. Thus our analysis excludes most SMEs and is an analysis of 
the characteristics of larger firms. A very small number of SMEs are included where the firms responding reported smaller numbers of employees than those shown in the sampling frame. Whilst, as we noted earlier, we include size as a control variable in our analysis, the exclusion of almost all SMEs from the data set limits the extent to which we can examine the effects of size.

The major thrust of the empirical analysis is to establish or confirm some of the major determinants of non-standard working by testing the specific hypotheses outlined above. Within the Cranet survey, data are recorded for three types of NSWT (overtime, shift working and weekend working). For each type of NSWT, the questionnaire asks each firm for an estimate of the proportion of employees undertaking that kind of working arrangement. Although the use of one respondent per firm is unsatisfactory for studies of a small number of firms, it is used widely as a method of collecting data in large scale surveys. Using block stepwise regression, each one of the three measures of NSWT was used as the dependent variable in three regression models estimated using ordinary least squares.

The independent variables were selected so as to enable testing of the hypotheses outlined earlier. First, a dummy is included to separate the CME countries from the reference category of the UK liberal market economy. This controls for differences across the varieties of capitalism as well as allowing hypothesis 1 to be tested. Next, a set of dummy variables is created separating the data into 16 different industries, metal manufacturing being used as the reference category, thus enabling both elements of 
hypothesis 2 to be explored. Finally, since Brewster et al (2007) established a strong relationship between employee voice mechanisms and HRM strategies, a dichotomous (dummy) variable is included to reflect the use of employee voice. The dummy separates those firms where communication to management takes place through collective voice mechanisms (i.e. works councils or trade union representatives) and those where such forms of communication are absent. This dummy variable facilitates the testing of hypotheses 3. A continuous variable is included to reflect the size of an organisation measured by the total number of employees. As noted above, it is used as a control variable.

Analyses are based on responses from 1530 companies in the five selected countries, the response rates to the survey were, for each country, as follows: UK $13.5 \%$, Germany 18.3\%, Austria 15.6\%, Sweden 22.5\% and Denmark 18.9\%. A typical company (mode) had 450 employees with over 90 per cent of them working on a full-time basis. Tables 1 and 2 report the descriptive statistics for the dependent variables by country and for the independent variables respectively. It is worth noting that within the respondent companies just under a half were drawn from the manufacturing sector.

<TAKE IN TABLES 1\& 2 ABOUT HERE>

\section{Findings}


The extent of NSWT within these companies is summarised in Table 3. It should be noted these are not exclusive categories and that companies reporting use of overtime might also report use of shift working and weekend working.

\section{<TAKE IN TABLE 3 ABOUT HERE>}

NSWT was used by a majority of the companies. Virtually all firms ( 89 per cent) used overtime; shift working (71 per cent of companies) and weekend working (60 per cent of companies) were less common. These data confirm the importance of NSWT in the economies of the five selected countries. Indeed, in one fifth of the companies more than 50 per cent of the employees were working overtime and/or shift working.

The models outlined in the methods section were then estimated and the findings are reported below in Table 4 .

\section{<TAKE IN TABLE 4 ABOUT HERE〉}

\section{Hypothesis 1}

In our first hypothesis, we suggested that specific forms of NSWT - overtime and shift work - would be more common in liberal market economies, reflecting both lighter regulation and weaker enforcement of any laws governing the extent of working time. It was tested by estimating overtime and shift work as functions of the explanatory 
variables, including the CME dummy. The analysis was also run for weekend working but differences were not expected.

On first inspection, it appears that overtime is more prevalent in LMEs. In the combined data set the CME dummy is negative $(-4.16)$ and significant $(\mathrm{p}<0.01)$, suggesting that once controls have been introduced for size, industry and employee voice there is less overtime within CME firms. However, it is difficult to support this finding since virtually none of the variation in the dependent variable is explained by the independent variables. It will be noted there is a very low R-squared result (0.03). This rather inconclusive finding in relation to overtime may arise from the fact that the term overtime is often used in a broad and sweeping manner, when closer scrutiny reveals that it encompasses a wide range of practices. These can vary from fully negotiated (and limited) overtime closely governed by collective agreements and/or law, to arbitrarily imposed increases in working hours that are disruptive to life outside work. Overtime, of this latter kind, could be defined as work both beyond the normal pre-agreed minimum working time and occurring outside the common social practice regarding working hours (e.g. the 9 to 5 working day).

The results relating to shift work are much stronger with an R-squared of 0.20 in the model combining data from the two different types of economy (Table 3). The negative coefficient (-4.15), which is highly significant ( $\mathrm{p}<0.01$ ), indicates shift work is less typical of CMEs and this confirms that part of our first hypothesis. It is a particularly 
strong result as the relationship appears significant even though we have introduced controls for size, industry and employee voice.

To complete the picture, the extent of weekend working does not appear to vary between the two different types of economy since the CME coefficient is not significant, even at the 10 per cent level. This is further confirmed by the raw data where the difference between the two economies is very small (Table 5).

\section{<INSERT TABLE 5 HERE>}

\section{Hypothesis 2}

Our second hypothesis explored the relationship between NSWT and sectoral mix. There are indeed marked variations in the proportions of NSWT between sectors (Table 6). Overtime was associated particularly with transport, building and other manufacturing but also with public administration. Shift work was a particular feature of the three manufacturing sectors and the health service. An important role for weekend working appeared in sectors with a number of continuous processes (chemicals) and those where consumer demand at weekends is a characteristic (retail, transport, personal services and health). Overall the initial part our second hypothesis of sectoral variation was confirmed.

<INSERT TABLE 6 HERE>

Nswtrevisedsubmission 
However, with regard to the second part of hypothesis 2, it was clear that the relationship between NSWT, sector and economy type was more complex and hidden within the combined data set, hence the models were re-estimated separately for LMEs and CMEs, with the results reported below in Table 7.

\section{<INSERT TABLE 7 HERE $>$}

Services represent an extremely broad area of economic activity, ranging from public services (in this data set provided through private sector providers), advanced high technology support services and financial services, through to low value added frontline services.

In the case of overtime, four service coefficients have a significant influence $(\mathrm{p}<0.01)$ on the amount of overtime undertaken in LMEs compared with only two in CMEs. This confirms hypothesis 2 in relation to overtime. Surprisingly, the significant sectoral mix coefficients in every case reduce the amount of overtime in LMEs but increase it in CMEs. We note particularly the contrasting influence of banking and finance in the two categories. A more parsimonious model distinguishing only between services and all other sectors produced similar results with overtime as the dependent variable (admittedly with very low R squares). Again, in LMEs, services showed a negative impact on overtime whilst in CMEs the impact was positive (both $\mathrm{p}<0.01$ )

The influence of sectors on shift working was the opposite of that expected. At the 0.01 level, in LMEs only one service sector variable had a significant influence on the extent 
of shift working whereas no less than four service sector variables had an influence in CMEs. Quite clearly, the service sector is not more likely to be an influence on the extent of shift working in LMEs than in CMEs. It is worth noting that the presence of banking and finance in both LMEs and CMEs reduced the amount of shift work. We would tentatively suggest that what is happening here is that flexibility is being achieved through the use of part time employees rather than making use of shift working amongst the full time employees. Retail and distribution and other services also had below average shift working and therefore, as expected, reduced the incidence of shift working.

The results in relation to weekend working, like those for shift working, were the opposite of those expected. Two significant service sector variables had an important influence in LMEs but no less than four service sector variables were important in CMEs. Where the coefficients appeared important in both forms of capitalism, they worked in the same direction. Companies in the retail and transport sectors were strongly associated with weekend working under both forms of capitalism, whereas health and personal services had a significant influence on weekend working only in CMEs.

\section{Hypothesis 3}

Hypothesis 3 suggested that NSWT may be correlated with collective employee voice and, in particular, that overtime will be more likely to be found where employee voice is absent. Although it can be argued that the relationship between employee voice and the dependent variables is more complex than the relationship suggested by this type of 
model (it is more complementary than causal), a negative relationship should still be revealed. However, in the combined data set, employee voice shows a positive association with overtime, shift work and weekend working (all $\mathrm{p}<0.01$ ).

This finding is particularly robust in that it appears in all the models (at varying levels of significance) except for the presence of overtime in CMEs. Identical results were obtained in the more parsimonious model (not shown here) using two sectors rather than fourteen. Both weekend work and shift work constitute mechanisms to redefine the working day, rather than simply extend it, as is the case with overtime. Consequently we largely found that collective voice was positively correlated with NSWT. Our overall expectation that collective voice would act to reduce NSWT was not supported.

Why would this be the case? First, it may be that unions are simply lukewarm to NSWT even if it has potentially negative consequences in terms of employment, it is not a pressing issue when compared to security, core pay and associated conditions. Second, Attitudes to NSWT may be positive in cases where such flexible working reflects the increasing importance of work/life balance issues. Third, it may be that, with the rise of more instrumental attitudes to work, employees are increasingly prepared to work longer for more money, even if they recognise the risks created by systematic overtime. Unions may be reluctant to antagonise their members in pursuit of an abstract collective good. Finally, it may be that unions are often forced to concede ground in this area, in order to maintain competitiveness, some jobs, and a presence at the firm in issue. It is possible that a combination of all these explanations could explain this apparent anomaly. 


\section{Conclusions}

We begin our summary and discussion of these findings with a caveat. This paper only examines formal NSWT and, as such, it does not take account of informal and unpaid NSWT that may be "expected" of employees, without it being formally recorded or reimbursed. Such unpaid NSWT is likely to be encountered in areas where employee rights are limited: in cases where the legal rights of employees are weak, and/or in organisations such as gang masters and family firms where, for very different reasons, informal ways of working regularly override formal contracts and employment law.

We found that there were considerable variations in the nature of NSWT and we have explored the extent to which this was related to different forms of capitalism, sectoral mix, the presence/absence of employee voice and size of firms. This has been explored within a multivariate framework. We have noted that NSWT allows firms to adjust their workforce sizes, without having to engage in the hiring of new staff, and/or making excessive use of redundancies. At the same time, forms of NSWT may have other benefits, in that they reduce the need to spend on induction training and, in a climate of greater job security, provide fertile ground for the development of organisation-specific human capital. The use of NSWT also may enable expensive plant and machinery to be used over a longer time period and for services to be provided for a greater part of the working day. 
Perhaps surprisingly, we did not find a clear link between variety of capitalism and the use of overtime. However, this is likely to reflect the fact that the latter embodies a wide range of practices, from the coerced extension of working hours to such an extent as to disrupt life outside work to modest increases and reductions that would enable firms to adjust the amount and cost of labour, without cutting or prematurely increasing jobs. Annual hours worked remain substantially larger in LMEs such as Britain and the US than they do in their coordinated continental European counterparts (Ewing 2003: 151; Williams and Adams-Smith 2006: 231-3) and it may be that our data is failing to identify less formal kinds of overtime working. Weak regulation and weaker enforcement may mean that unofficial overtime is more likely to take place in LMEs (see Ackers and AlSawad 2006; Hollinshead et al. 1999) and less likely to be detected by a survey of employers. However, in terms of hypothesis 1, shift-working did show an unequivocal distinction between the two varieties of capitalism we have considered. Shift work is less typical of CMEs.

We found important sectoral variations in the usage of NSWT. Examination of the raw data illustrated that the proportions of the different forms of NSWT varied between sectors, thus confirming the first part of hypothesis 2 . In testing the second part of hypothesis 2 we were able to show that, as expected, the service sector had a strong influence on the amount of overtime in LMEs but not CMEs. The opposite was true for shift working and weekend working. Thus the second part of hypothesis 2 could be accepted in the case of overtime but rejected in relation to shift work and weekend working. 
Finally, in relation to hypothesis 3 , we found that stronger employee voice was associated with extensive use of overtime, the opposite of the relationship we had expected. Some suggestions as to why this outcome might have arisen were outlines earlier.

Our study has pointed to a rich variation in the extent and nature of NSWT between countries. We found no evidence of uniform practices within any area of NSWT, reflecting the persistence of diversity. It is evident that both "cooperative" non-standard arrangements, supplementing and supporting other flexible working practices and strong and effective employee voice, and poorly rewarded working over extended hours, including weekends, represent the product of a wide range of forces, including industry and spatially specific production paradigms, and informal and formal regulations. The use of NSWT may represent a way of helping secure jobs (through allowing firms to adjust workforce sizes without firing or premature hiring) and, hence, promote greater organisational commitment, and engender organisation specific human capital development. Alternatively, they may represent a semi-coerced form of "extra" working that may be unduly stressful, and disrupt social life.

This would suggest that a fertile avenue for future research would be a closer examination of the range of formal and informal overtime working under the different forms of capitalism. 
Fertile areas for future enquiry into the contrasts between NSWT under different forms of capitalism would include a closer examination of overtime (both formal and informal) and the relationship between the strength of employee voice, functionally flexible production and the relative length of work that employees may engage in outside of normal working hours. Extension of the evidence to other, particularly non-European, countries would be useful as would a comparison of our results with more sophisticated studies depicting more than two varieties of capitalism (Amable 2003; Jackson and Deeg 2007; Whitley 1999). Finally, there is a need for a very much closer examination of the relationship between work, non-work and non-standard working 


\section{References}

Ackers, P. and Al-Sawad, A. (2006), 'Family Friendly Policies and Work Life Balance,' in Contemporary Human Resource Management, eds. Redman, A. and Wilkinson, A, London: FT-Prentice Hall.

Almond, P. and Gonzalez, M. (2006), 'Varieties of capitalism: The importance of political and social choices', Transfer, 12:3:407-425.

Amable, B. (2003), The Diversity of Modern Capitals, Oxford: Oxford University Press

Berg, P., Appelbaum, E., Bailey, T. and Kalleberg, A. (2004), 'Contesting Time: International Comparisons of Employee Control of Working Time,' Industrial and Labor Relations Review, 57, 331-349.

Boisard, P., Cartron, D., Gollac, M. and Valeyre, A. (2002), Temps et Travail: la Durée du Travail, Dublin: European Foundation for the Improvement of Living and Working Conditions.

Boisard, P. (2003), Time Constraints and Health Risks in Europe, Dublin: European Foundation for the Improvement of Living and Working Conditions.

Brewster, C. (1998), 'Flexible working in Europe: extent, growth and challenge for HRM' in HRM the New Agenda, eds. P. Sparrow and M. Marchington, London: Pitman

Brewster, C., Brookes, M., Croucher, R. and Wood, G. (2007), 'Collective and Individual Voice: Convergence in Europe?' International Journal of Human Resource Management, 18, 1246-1262.

Brewster, C., Brookes, M. and Wood, G. (2006), 'Varieties of Capitalism and Varieties of Firm,' in Institutions, Production and Working Life, eds, G. Wood and P. James, Oxford: Oxford University Press. 
Brewster, C., Mayrhofer, W. and Morley, M., (eds.) (2004), Human Resource Management in Europe: Evidence of Convergence? London: Butterworth Heinemann.

Brewster, C., Mayne, L. and Tregaskis, O. (1997), 'Flexible Working in Europe', Journal of World Business, 32, 133-151.

Cousins, C.R. and Tang, N (2004), 'Working Time and Work and Family Conflict in the Netherlands, Sweden and the UK,' Work, Employment and Society, 18, 531-549.

Djankov, S., Glaeser, E., La Porta, R., Lopez-de-Silnes, F. and Shleifer, A. (2003), 'The New Comparative Economics', Journal of Comparative Economics, 31: 595-619.

Dore, R. (2000), Stock Market Capitalism: Welfare Capitalism, Cambridge: Cambridge University Press.

Ewing, K. (2003), 'Labour Law and Industrial Relations,' in Understanding Work and Employment, eds. P. Ackers, and A. Wilkinson, Oxford: Oxford University Press.

Gall, G. (2003), 'Conclusion: Drawing up the Balance Sheet,' in Gall, G. (ed.), Union Organizing, ed. Gall G, London: Routledge.

Hall, P. and Soskice, D. (2001), 'An Introduction of Varieties of Capitalism,' in Varieties of Capitalism: The Institutional Basis of Competitive Advantage, eds. P. Hall and D. Soskice, Oxford: Oxford University Press.

Harcourt, M. and Wood, G. (2007), 'The Importance of Employment Protection for Skill Development in Coordinated Market Economies', European Journal of Industrial Relations, 13, 141-159.

Harris, L. (2002), 'Small Firm Responses to Employment Regulation,' Journal of Small Business and Enterprise Development, 9, 206-236. 
Hollinshead, G., Nicholls, P. and Tailby, S. (1999), Employee Relations, London: FTPitman.

Hyman, J. (2006), 'Remaking of Work: Empowerment or Degradation?', Wood, G. and James, P. (eds.), Institutions, Production and Working Life, Oxford: Oxford University Press.

Jackson, G. and Deeg, R. (2007), Comparative Capitalisms: Understanding Institutional Diversity and its Implications for International Business, Journal of International Business Studies, 39, 540-561.

Kenner, J. (2004), Re-evaluating the Concept of Working Time: an Analysis of Recent Case Law, Industrial Relations Journal, 35, 588-602.

Kreitzman, L. (1999), The Twenty Four Hour Society, London: Profile Books.

Lane, C. and Wood, G. (2009), 'Introducing Diversity in Capitalism and Capitalist Diversity', Economy and Society, 38, 3.

La Porta, R., Lopez-de-Silanes, F., Shleifer, A. and Vishny, R. (1998), 'Law and Finance', Journal of Political Economy, 106, 1113-1155.

Lee, S., McCann, D. and Messenger J. C. (2007), Working Time Around the World: Trends in Working Hours, Laws and Policies in a Global Comparative Perspective, London and New York: Routledge.

Lincoln, J. and Kalleberg, A. (1990), Culture, Control and Commitment: A Study of Work Organization in the United States and Japan, Cambridge: Cambridge University Press.

McOrmond, T. (2004), 'Changing Working Trends Over the Past Decade,' Labour Market Trends, January, 25-35. 
Marsden, D. (1999), A Theory of Employment Systems, Oxford: Oxford University Press.

Martin, G. (2006), Managing People and Organizations in Changing Contexts, London: Butterworth Heinemann.

OECD (2003), Employment Outlook, Paris: OECD.

Parry, E., Dickmann, M. and Morley, M. (2008), North American MNCs and Their HR Policies in Liberal and Coordinated Market Economies,' International Journal of Human Resource Management, 19, 2024 -2040.

Polivk, A. E. and Nardone, T. (1989), 'The Definition of Contingent Work,' Monthly Labour Review, 112, 9-16.

Raghuram, S., London, M. and Larsen, H.H. (2001) 'Flexible Employment Practices in Europe: Country versus Culture,' International Journal of Human Resource Management, 12, $738-753$.

Richbell, S. and Kite, V. (2007), 'Night Shoppers in an 'Open 24 Hours' Supermarket: a Profile,' International Journal of Retail and Distribution Management, 35, 54 68.

Sayer, A. (2006), 'Organisational Life: The Good, the Bad, and the Instrumental', Wood, G. and James, P. (eds.), Institutions, Production and Working Life, Oxford: Oxford University Press.

Supiot, A. (2001), Beyond Employment: Changes in Work and the Future of Labour in Europe, Oxford: Oxford University Press.

Thelen, K. (2001), 'Varieties of Labor Politics in the Developed Democracies', in Hall, P. and Soskice, D. (eds.), Varieties of Capitalism: The Institutional Basis of Competitive Advantage. Oxford: Oxford University Press. 
Tregaskis, O. and Brewster, C. (2006), 'Convergence and Divergence: The Example of Contingent Employment Practices over a Decade,' Journal of International Business Studies, 37, 111-126.

Tregaskis, O., Brewster, C., Mayne, L. and Hegewisch, A. (1998), 'Flexible Working in Europe: the Evidence and the Implications' European Journal of Work, Organisation and Psychology, 7, 61-78.

Whitley, R. (1999), Divergent Capitalisms, Oxford: Oxford University Press.

Williams, S. and Adams-Smith, D. (2006), Contemporary Employment Relations, Oxford: Oxford University Press.

Wilson, M. G., Polzer-Debruyne, A., Chen, S and Fernandes, S. (2005), 'Shift Work Interventions for Reduced Work-family Conflict,' Employee Relations, 29, $162-$ 177.

Wood, G., Harcourt, M., and Roper, I. (2006), 'The Limits of Numerical Flexibility: Continuity and Change,' in Institutions, Production and Working Life, eds, G. Wood, and P. James, Oxford: Oxford University Press. 
Table 1 Descriptive Statistics: Dependent Variables

\begin{tabular}{|c|c|c|c|c|c|c|c|}
\hline & \multicolumn{2}{|c|}{ Overtime* } & \multicolumn{2}{|c|}{ Shift Work* } & \multicolumn{2}{|c|}{ Weekend Working* } & \multirow{2}{*}{$\begin{array}{c}\text { Observations } \\
\mathrm{n}\end{array}$} \\
\hline & $\begin{array}{c}\text { Mean } \\
\%\end{array}$ & $\begin{array}{l}\text { Standard } \\
\text { Deviation }\end{array}$ & $\begin{array}{c}\text { Mean } \\
\%\end{array}$ & $\begin{array}{l}\text { Standard } \\
\text { Deviation }\end{array}$ & $\begin{array}{c}\text { Mean } \\
\%\end{array}$ & $\begin{array}{l}\text { Standard } \\
\text { Deviation }\end{array}$ & \\
\hline UK & 26.84 & 26.06 & 24.07 & 29.53 & 12.06 & 21.82 & 656 \\
\hline Germany & 9.53 & 18.33 & 28.71 & 29.53 & 15.93 & 23.81 & 222 \\
\hline Austria & 14.47 & 17.37 & 26.96 & 30.15 & 13.11 & 22.69 & 178 \\
\hline Sweden & 25.55 & 25.46 & 26.62 & 29.26 & 14.75 & 24.69 & 223 \\
\hline Denmark & 44.49 & 30.45 & 15.05 & 24.71 & 5.75 & 14.00 & 251 \\
\hline
\end{tabular}

* Proportion of employees in a firm working under specified work pattern

Source: CRANET 
Table 2 Descriptive Statistics: Independent Variables

\begin{tabular}{|l|c|c|c|c|}
\hline \multicolumn{1}{|c|}{ Variable } & Mean & $\begin{array}{c}\text { Standard } \\
\text { Deviation }\end{array}$ & Minimum & Maximum \\
$\begin{array}{l}\text { Continuous Variable } \\
\text { Total employees }\end{array}$ & 1905.0 & 9903 & 25 & 211063 \\
$\quad$ Dummy Variables & & 0.16 & 0 & 1 \\
Energy and water & 0.025 & 0.19 & 0 & 1 \\
Chemical products & 0.037 & 0.42 & 0 & 1 \\
Metal manufacturing & 0.227 & 0.41 & 0 & 1 \\
Other manufacturing & 0.210 & 0.19 & 0 & 1 \\
Building & 0.039 & 0.32 & 0 & 1 \\
Retail and distribution & 0.114 & 0.23 & 0 & 1 \\
Transport & 0.054 & 0.33 & 0 & 1 \\
Banking and finance & 0.125 & 0.10 & 0 & 1 \\
Personal services & 0.009 & 0.13 & 0 & 1 \\
Health services & 0.018 & 0.15 & 0 & 1 \\
Other services & 0.024 & 0.08 & 0 & 1 \\
Education & 0.006 & 0.05 & 0 & 1 \\
Social services & 0.003 & 0.14 & 0 & 1 \\
Public administration & 0.019 & 0.29 & 0 & 1 \\
Other & 0.090 & 0.43 & 0 & 1 \\
Employee voice & 0.749 & 0.50 & 0 & 1 \\
CME & 0.571 & &
\end{tabular}

Source: CRANET 
Table 3 NSWT in five selected EU countries

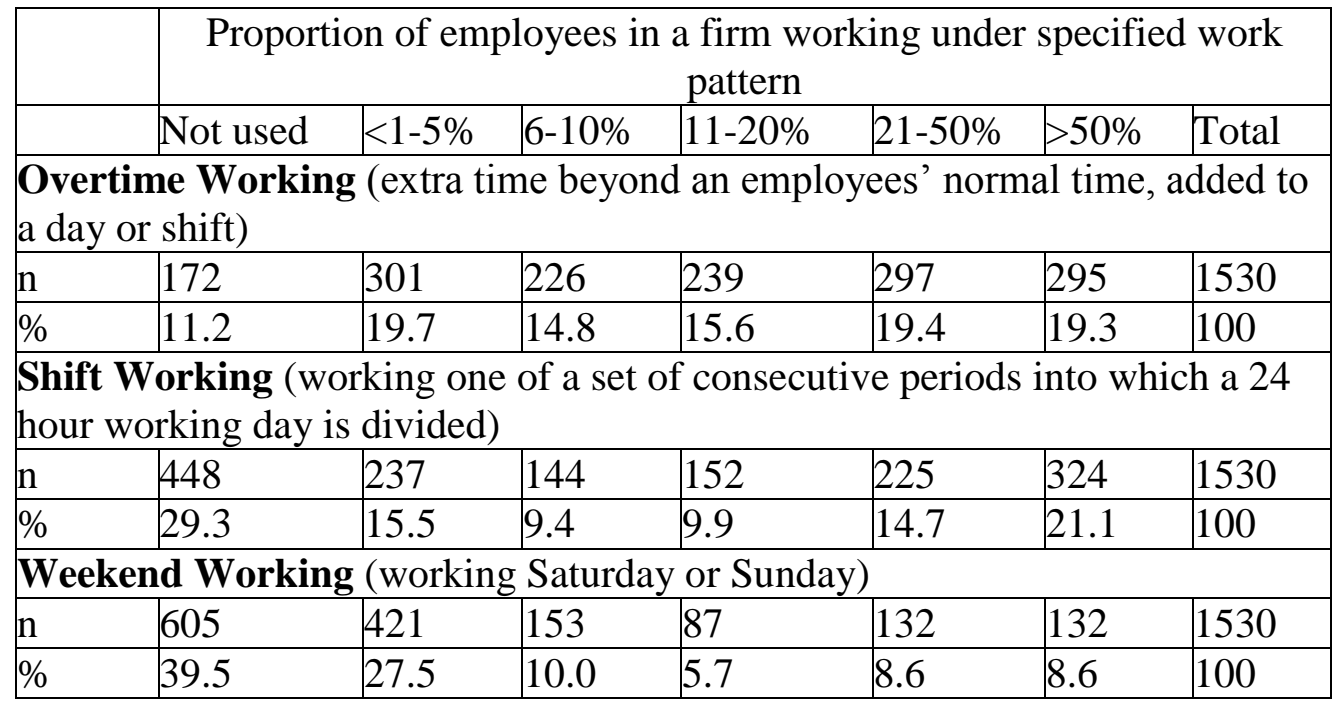

Source: CRANET 
Table 4: $\quad$ OLS Models of NSWT

\begin{tabular}{|c|c|c|c|c|c|c|c|}
\hline & $\begin{array}{l}\text { Ove } \\
\text { Tim }\end{array}$ & & $\begin{array}{l}\text { Shif } \\
\text { Nork }\end{array}$ & & & $\begin{array}{l}\text { aken } \\
\text { orking }\end{array}$ & \\
\hline & Coeff. & t-ratio & Coeff. & t-ratio & Coeff. & t-ratio & Mean \\
\hline Constant & $20.60^{\star \star \star}$ & 9.87 & $21.86^{\star \star \star}$ & 10.71 & $3.96^{\star \star \star}$ & 2.49 & \\
\hline Total employees (000s) & 0.03 & 0.44 & 0.06 & 0.86 & $0.21^{* * *}$ & 4.01 & 1.91 \\
\hline Energy and water & -1.68 & -0.37 & $-15.24^{\star \star *}$ & -3.44 & 3.34 & 0.97 & 0.03 \\
\hline Chemical products & -0.84 & -0.22 & $9.14^{\star \star *}$ & 2.43 & $10.09^{* * *}$ & 3.45 & 0.04 \\
\hline Other manufacturing & $3.56^{*}$ & 1.71 & $11.83^{* * *}$ & 5.82 & $4.51^{\star * *}$ & 2.85 & 0.21 \\
\hline Building & $6.26^{*}$ & 1.66 & $-16.92^{* * *}$ & -4.60 & 2.51 & 0.88 & 0.04 \\
\hline Retail and distribution & -0.10 & -0.04 & $-7.61^{* \star *}$ & -3.07 & $20.79^{\star * *}$ & 10.76 & 0.11 \\
\hline Transport & 1.80 & 0.55 & 3.26 & 1.01 & $14.74^{* * *}$ & 5.87 & 0.05 \\
\hline Banking and finance & -0.16 & -0.06 & $-22.60^{\star * *}$ & -9.33 & -2.67 & -1.42 & 0.13 \\
\hline Personal services & -10.33 & -1.41 & -10.82 & -1.51 & $21.62^{* * *}$ & 3.88 & 0.01 \\
\hline Health services & -7.08 & -1.35 & 2.74 & 0.53 & $21.90^{\star \star \star}$ & 5.46 & 0.02 \\
\hline Other services & -3.79 & -0.81 & $-15.32^{* * *}$ & -3.33 & 4.28 & 1.20 & 0.02 \\
\hline Education & -14.24 & -1.57 & $-19.74^{* *}$ & -2.23 & -3.20 & -0.46 & 0.01 \\
\hline Social services & -2.66 & -0.20 & -8.25 & -0.63 & 15.48 & 1.51 & 0.003 \\
\hline Public administration & 2.38 & 0.45 & $-10.85^{\star *}$ & -2.11 & $6.89^{*}$ & 1.72 & 0.02 \\
\hline Other & 3.15 & 1.15 & $-8.82^{* * *}$ & -3.30 & $5.45^{\star * *}$ & 2.62 & 0.09 \\
\hline Employee voice & $8.55^{\star \star *}$ & 4.82 & $10.24^{\star * *}$ & 5.89 & $3.65^{\star \star \star}$ & 2.70 & 0.75 \\
\hline CME & $-4.16^{\star * \star}$ & -2.75 & $-4.15^{\star \star \star}$ & -2.80 & -1.18 & -1.03 & 0.57 \\
\hline Dependent Variable & Overtime & & Shift work & & Weekend w & rking & \\
\hline Mean & 25.59 & & 23.97 & & 12.10 & & \\
\hline Number of observations & 1530 & & 1530 & & 1530 & & \\
\hline R-squared & 0.03 & & 0.20 & & 0.14 & & \\
\hline
\end{tabular}

Source: CRANET

Nswtrevisedsubmission 
Table 5 Weekend Working by type of economy

\begin{tabular}{|c|c|c|c|c|c|c|c|c|}
\hline \multirow[t]{2}{*}{ Economy } & & \multicolumn{7}{|c|}{ Proportion of employees undertaking weekend working } \\
\hline & & Not used & $<1-5 \%$ & $6-10 \%$ & $11-20 \%$ & $21-50 \%$ & $>50 \%$ & Total \\
\hline LME & $n$ & 272 & 162 & 70 & 36 & 60 & 56 & 656 \\
\hline & $\%$ & 41.4 & 24.7 & 10.7 & 5.5 & 9.1 & 8.5 & 100 \\
\hline $\mathrm{CME}$ & n & 332 & 260 & 84 & 51 & 72 & 75 & 874 \\
\hline & $\%$ & 38.0 & 29.7 & 9.6 & 5.8 & 8.2 & 8.6 & 100 \\
\hline
\end{tabular}

Source: CRANET 
Table 6 Mean proportions of NSWT by Industrial Sector

\begin{tabular}{|c|c|c|c|}
\hline & Overtime & Shift Work & Weekend Working \\
\hline Energy and water & 22.8 & 13.8 & 9.8 \\
Chemical products & 23.9 & $\mathbf{3 6 . 9}$ & $\mathbf{1 6 . 5}$ \\
Metal manufacturing & 25.4 & $\mathbf{2 8 . 3}$ & 6.5 \\
Other manufacturing & $\mathbf{2 8 . 9}$ & $\mathbf{3 9 . 6}$ & 10.7 \\
Building & $\mathbf{2 9 . 3}$ & 9 & 8.6 \\
Retail and distribution & 23.6 & 18.5 & $\mathbf{2 6 . 8}$ \\
Transport & $\mathbf{2 6 . 1}$ & $\mathbf{3 0 . 9}$ & $\mathbf{2 0 . 9}$ \\
Banking and finance & 22.4 & 2.5 & 2.9 \\
Personal services & 12.7 & 14.9 & $\mathbf{2 5 . 8}$ \\
Health services & 17.2 & $\mathbf{2 9 . 8}$ & $\mathbf{2 8 . 3}$ \\
Other services & 19.8 & 10.8 & 9.9 \\
Education & 8.5 & 5.6 & 2.3 \\
Social services & 23.3 & 20.8 & 22 \\
Public administration & $\mathbf{2 7 . 1}$ & 18.2 & $\mathbf{1 7 . 4}$ \\
Other & $\mathbf{2 6 . 6}$ & 16.9 & 11.1 \\
\hline Total & 25.5 & 23.8 & 11.9 \\
\hline
\end{tabular}

* Sectors above mean for specified form of NSWT shown in bold

Source: CRANET 
Table 7: $\quad$ OLS Models of NSWT by Economy Type

\begin{tabular}{|c|c|c|c|c|c|c|c|c|c|c|c|c|c|c|}
\hline & \multicolumn{3}{|l|}{ LME } & \multicolumn{3}{|l|}{ CME } & \multicolumn{2}{|c|}{ LME } & \multicolumn{2}{|l|}{ CME } & \multicolumn{2}{|l|}{ LME } & \multicolumn{2}{|c|}{ CME } \\
\hline & Coeff. & t-ratio & Mean & Coeff. & t-ratio & Mean & Coeff. & t-ratio & Coeff. & t-ratio & Coeff. & t-ratio & Coeff. & t-ratio \\
\hline Constant & $27.43^{\star \star \star}$ & 9.95 & & $17.02^{\star \star \star}$ & 5.13 & & $19.45^{\star \star \star}$ & 6.68 & $21.33^{\star * \star}$ & 6.81 & $4.67^{\star \star}$ & 2.09 & 2.13 & 0.87 \\
\hline Total employees (000s) & 0.13 & 1.52 & 2.32 & -0.08 & -0.70 & 1.59 & 0.07 & 0.84 & -0.02 & -0.15 & $0.18^{* * *}$ & 2.60 & $0.26^{* * *}$ & 2.98 \\
\hline Energy and water & -0.17 & -0.02 & 0.02 & -0.35 & -0.06 & 0.03 & $-15.99^{*}$ & -1.85 & $-14.85^{\star \star \star}$ & -2.89 & -6.54 & -0.99 & $6.93^{*}$ & 1.72 \\
\hline Chemical products & 3.89 & 0.45 & 0.01 & 0.76 & 0.17 & 0.05 & 9.83 & 1.08 & $8.97^{\star \star}$ & 2.16 & 2.46 & 0.35 & $11.93^{* * *}$ & 3.68 \\
\hline Other manufacturing & 0.59 & 0.20 & 0.24 & 4.03 & 1.42 & 0.19 & $8.82^{\star \star \star}$ & 2.81 & $14.62^{\star * *}$ & 5.45 & 3.24 & 1.34 & $5.37^{\star \star \star}$ & 2.56 \\
\hline Building & -8.40 & -1.58 & 0.04 & $15.89^{\star \star *}$ & 3.08 & 0.04 & $-18.94^{* * *}$ & -3.37 & $-15.08^{\star * *}$ & -3.09 & 3.18 & 0.74 & 1.85 & 0.49 \\
\hline Retail and distribution & $-8.91^{* * *}$ & -2.46 & 0.13 & 4.46 & 1.28 & 0.10 & -1.65 & -0.43 & $-12.78^{* * *}$ & -3.89 & $23.55^{\star \star *}$ & 8.01 & $18.18^{\star \star \star}$ & 7.08 \\
\hline Transport & -6.93 & -1.35 & 0.04 & $7.14^{\star}$ & 1.68 & 0.06 & 3.29 & 0.61 & 3.72 & 0.93 & $11.61^{* * *}$ & 2.79 & $16.34^{* * *}$ & 5.20 \\
\hline Banking and finance & $-14.10^{\star \star \star}$ & -3.95 & 0.14 & $10.08^{* * *}$ & 2.99 & 0.11 & $-19.96^{\star \star \star}$ & -5.29 & $-23.87^{\star * *}$ & -7.49 & -3.54 & -1.22 & -1.96 & -0.79 \\
\hline Personal services & -19.44 & -0.78 & 0.002 & -6.47 & -0.82 & 0.01 & -19.46 & -0.74 & -9.85 & -1.33 & -4.69 & -0.23 & $24.22^{\star \star \star}$ & 4.17 \\
\hline Health services & -8.98 & -0.99 & 0.01 & -5.52 & -0.86 & 0.02 & -6.22 & -0.65 & 6.60 & 1.09 & -1.70 & -0.23 & $31.65^{\star \star *}$ & 6.66 \\
\hline Other services & $-22.38^{* * *}$ & -2.60 & 0.01 & 3.36 & 0.60 & 0.03 & $-20.53^{\star *}$ & -2.26 & $-13.65^{\star \star *}$ & -2.57 & -3.81 & -0.55 & $7.32^{*}$ & 1.76 \\
\hline Education & $-25.42^{\star *}$ & -2.24 & 0.01 & -5.70 & -0.41 & 0.005 & -14.83 & -1.23 & $-25.25^{\star}$ & -1.92 & -2.10 & -0.23 & -5.04 & -0.49 \\
\hline Social services & -20.03 & -0.80 & 0.002 & 5.01 & 0.31 & 0.003 & -33.32 & -1.26 & 0.10 & 0.01 & -0.82 & -0.04 & $21.18^{*}$ & 1.79 \\
\hline Public administration & -5.75 & -1.09 & 0.04 & 18.51 & 0.94 & 0.002 & $-12.82^{\star *}$ & -2.29 & 13.05 & 0.71 & 4.18 & 0.97 & $33.49^{* *}$ & 2.31 \\
\hline Other & $-9.36^{\star * *}$ & -2.44 & 0.10 & $11.63^{* * *}$ & 3.07 & 0.08 & $-6.54^{*}$ & -1.61 & $-10.53^{\star * *}$ & -2.95 & $6.74^{\star \star}$ & 2.16 & 4.08 & 1.46 \\
\hline $\begin{array}{l}\text { Employee voice } \\
\qquad \mathrm{CME}\end{array}$ & $8.06^{\star \star \star}$ & 3.70 & 0.57 & 3.99 & 1.36 & 0.88 & $13.85^{\star \star *}$ & 6.01 & $6.24^{\star \star}$ & 2.24 & $4.09^{* *}$ & 2.31 & $3.65^{*}$ & 1.68 \\
\hline Dependent Variable & \multicolumn{3}{|l|}{ Overtime } & \multicolumn{3}{|l|}{ Overtime } & \multicolumn{2}{|l|}{ Shift work } & \multicolumn{2}{|l|}{ Shift work } & \multicolumn{2}{|c|}{ Weekend work } & \multicolumn{2}{|c|}{ Weekend work } \\
\hline Mean & \multicolumn{3}{|l|}{26.84} & \multicolumn{3}{|l|}{24.66} & \multicolumn{2}{|l|}{24.07} & \multicolumn{2}{|l|}{23.89} & \multicolumn{2}{|c|}{12.06} & \multicolumn{2}{|c|}{12.13} \\
\hline No. of observations & \multicolumn{3}{|l|}{656} & \multicolumn{3}{|l|}{874} & \multicolumn{2}{|l|}{656} & \multicolumn{2}{|l|}{874} & \multicolumn{2}{|l|}{656} & \multicolumn{2}{|l|}{874} \\
\hline R-squared & \multicolumn{3}{|l|}{0.11} & \multicolumn{3}{|l|}{0.04} & \multicolumn{2}{|l|}{0.23} & \multicolumn{2}{|l|}{0.20} & \multicolumn{2}{|l|}{0.17} & \multicolumn{2}{|l|}{0.15} \\
\hline
\end{tabular}

\section{Source: CRANET}

